\title{
Utility of ribotyping, restriction endonuclease analysis and pulsed-field gel electrophoresis to discriminate between isolates of Neisseria gonorrhoeae of serovar IA-2 which require arginine, hypoxanthine or uracil for growth
}

\author{
HUI LI* and JO-ANNE R. DILLON*† \\ " Department of Biology, University of Ottawa and + National Laboratory for Sexually Transmitted Diseases, \\ Laboratory Centre for Disease Control, Ottawa, Canada
}

\begin{abstract}
Summary. Neisseria gonorrhoeae isolates that require arginine-i.e., either citrulline (C), or ornithine $(\mathrm{O})$ - uracil $(\mathrm{U})$ and hypoxanthine $(\mathrm{H})$ have generally been considered to be similar when characterised by auxotype, serovar and plasmid content. The MICs of penicillin, tetracycline, erythromycin, spectinomycin, cefoxitin and ceftriaxone for 552 isolates belonging to serovar IA-2 with these phenotypes were found to be similar. Therefore, restriction fragment length polymorphism analysis of rRNA genes (ribotyping), restriction enzyme (RE) analysis of chromosomal DNA, and pulsed-field gel electrophoresis (PFGE) were evaluated to determine whether these isolates could be distinguished by molecular methods. A subset of 27 isolates of $N$. gonorrhoeae that were OUH-requiring, CUH-requiring or OH-requiring, belonged to serovar IA-2 and carried a 2.6-MDa plasmid, were selected for further study. Based on the RE analysis of SmaI-digested genomic DNA, the 27 isolates fell into a single RE pattern, five ribotypes and 17 PFGE profiles which did not correlate with the specific arginine-requiring subtypes of these isolates. Each ribotype varied by the presence of only a single fragment, which was of a different size in each pattern, and $17(63 \%)$ of the 27 isolates belonged to ribotype I. PFGE yielded the highest level of discrimination with 17 different profiles.
\end{abstract}

\section{Introduction}

Neisseria gonorrhoeae isolates require various compounds for growth in chemically defined media. ${ }^{1}$ Arginine auxotrophy is one of the most frequently encountered nutritional defects in gonococcal isolates in Canada, and is found in $40-60 \%$ of clinical isolates. ${ }^{2}$ Arginine-requiring (A) isolates can be subtyped by auxotype into citrulline-requiring (C) or ornithinerequiring $(\mathrm{O})$ isolates. ${ }^{3}$ Isolates that require arginine (i.e., require ornithine or citrulline) as well as hypoxanthine and uracil $\left(\mathrm{AHU}^{-}\right)$have increased sensitivity to penicillin and are resistant to the bactericidal action of normal human serum; they have also been associated with disseminated gonococcal infection. ${ }^{4.5}$ Most AHU-requiring strains belonging to serovar IA-2 have been previously considered to be

Received 30 Jan. 1995; accepted 23 Feb. 1995.

$\dagger$ Present address and address for correspondence: Department of Microbiology and Immunology, University of Ottawa Faculty of Medicine, 451 Smyth Road, Ottawa, Ontario K1H 8M5, Canada. clonal since they generally cannot be distinguished by antibiogram or plasmid content. ${ }^{6}$

With a homogeneous group of isolates, the discriminatory capacity of classical gonococcal typing schemes-such as auxotyping, serotyping and plasmid content analysis-is often not powerful enough to distinguish between isolates of the same class. ${ }^{7}$ Several molecular methods have been used to subtype gonococcal isolates, including restriction endonuclease (RE) analysis, ${ }^{8,9}$ ribotyping, ${ }^{10,11}$ multilocus enzyme electrophoresis ${ }^{10,12}$ and pulsed-field gel electrophoresis (PFGE) ${ }^{10,13,14}$ although few of these studies have specifically included the AHU-requiring class of isolates. ${ }^{10,14}$

In the present study, $552 \mathrm{AHU}$-requiring isolates of serovar IA- 2 were typed by antimicrobial susceptibility and plasmid content to provide the relevant context for molecular subtyping. $\mathrm{CUH}^{-}$and $\mathrm{OUH}^{-}$isolates of serovar IA-2 were analysed, as well as $\mathrm{OH}^{-}$isolates which were similar to $\mathrm{CUH}^{-}$and $\mathrm{OUH}^{-}$isolates by antibiogram and plasmid content. These epidemiologically unrelated isolates-which were pheno- 
typically identical with respect to antibiogram, plasmid content (each carried a plasmid of $2.6 \mathrm{MDa}$ ) and their serovar (IA-2) - were further characterised by ribotyping, RE analysis and PFGE to determine whether they were identical.

\section{Materials and methods}

\section{Bacterial strains and culture conditions}

In total, 552 serovar IA-2 isolates-subtyped as auxotypes $\mathrm{OUH}^{-}(459 ; 83.2 \%), \mathrm{CUH}^{-}(61 ; 11.1 \%)$ and $\mathrm{OH}^{-}(32 ; 5.8 \%)$ isolates-collected between 1988 and 1992, were obtained from the culture collection of the National Laboratory for Sexually Transmitted Diseases (NLSTD), Laboratory Centre for Disease Control, Ottawa, Canada. Twenty-seven of these isolates of diverse geographical origins in Canada and different isolation dates were selected for further study. The 12 OUH-requiring isolates (nos. 880375, 880420, $881035,882208,882245,882306,882398,882521$, $883122,883171,883342$ and 883463 ) were from eight provinces; the eight CUH-requiring isolates (nos. $880270,880379,880454,881540,882132,882610$, 883099 and 883729 ) were from four provinces; and the seven $\mathrm{OH}$-requiring isolates (nos. 881097, 881342, $881506,882376,882642,882794$ and 883212) were from four provinces in Canada.

$N$. gonorrhoeae isolates were either frozen previously at $-70^{\circ} \mathrm{C}$ in Brain Heart Infusion Broth (Difco) plus glycerol $15 \% \mathrm{v} / \mathrm{v}$, or were lyophilised in skimmed milk $2 \% \mathrm{w} / \mathrm{v}^{15}$ or horse serum plus inositol $5 \% \mathrm{w} / \mathrm{v}$. Gonococci were subcultured on GC Medium Base (GCMB; Difco), supplemented with modified defined supplement $1 \% \mathrm{v} / \mathrm{v}^{16}$ and were incubated for $18-24 \mathrm{~h}$ at $35^{\circ} \mathrm{C}$ in a humid atmosphere supplemented with $\mathrm{CO}_{2} 5 \% \mathrm{v} / \mathrm{v}$.

Escherichia coli strain $\mathrm{C} 600$ carrying plasmid pKK3535 (supplied by Dr J. Brosius, Columbia University, New York, NY, USA), containing the $r r n B$ operon, ${ }^{10,17}$ was grown on Tryptic Soy Agar (TSA; Difco) supplemented with ampicillin (Sigma) $100 \mathrm{mg} / \mathrm{L}$ and incubated at $37^{\circ} \mathrm{C}$ overnight.

\section{Auxotype, serovar and plasmid content determination}

The auxotype of the $N$. gonorrhoeae isolates was determined by a modification ${ }^{16}$ of the method of Hendry and Stewart. ${ }^{18}$ Serovar was determined as described by Knapp et al.$^{19}$ Monoclonal antibodies for serovar determination were provided by Syva (Palo Alto, CA, USA). Isolates were analysed for plasmid content as described previously. ${ }^{20}$

\section{Antimicrobial susceptibility testing}

The MICs of penicillin, tetracycline, erythromycin, cefoxitin, ceftriaxone and spectinomycin for the isolates were determined by an agar dilution method. ${ }^{21}$ The media contained Kellogg's Defined Supplement
$1 \% \mathrm{v} / \mathrm{v}^{15}$ and the bacterial inoculum was prepared in auxotyping minimal medium. ${ }^{6}$

\section{$R E$ analysis and ribotyping}

To isolate genomic DNA, $N$. gonorrhoeae cells were lysed by the method of Dillon et al ${ }^{22}$ Chromosomal DNA $(c .10 \mu \mathrm{g})$ was digested with SmaI, AvaII or HindII according to the manufacturer's instructions (Boehringer Mannheim), followed by electrophoresis in NA agarose (Pharmacia) $0.7 \% \mathrm{w} / \mathrm{v}$ gels for $40 \mathrm{~h}$ at constant voltage $(25 \mathrm{~V})$ in Tris-acetate (TA) buffer ( $400 \mathrm{~mm}$ Tris-base $200 \mathrm{~mm}$ sodium acetate and $18 \mathrm{~mm}$ EDTA, pH 7.8). Molecular size markers included lambda DNA (BRL), lambda DNA digested with $K p n I$, and a 1-kb ladder (BRL). Gels were stained and photographed as described previously. ${ }^{10}$ Fragment sizes from at least three gels were averaged after measuring distances of band migration in comparison to DNA standards.

The riboprobe, comprising the $7 \cdot 2-\mathrm{kb}$ Bam HI-PstI fragment from plasmid pKK3535, was prepared as described previously ${ }^{10}$ and labelled with ${ }^{32} \mathrm{P}-\mathrm{dCTP}$ (Dupont) by the random primer-Klenow polymerase method $^{23}$ with a Megaprime Labelling Kit (Amersham) in accordance with the manufacturer's instructions.

DNA was transferred from agarose gels to a positively-charged nylon membrane (BMC) by the alkaline transfer method. ${ }^{24}$ Hybridisation with the radioactive-labelled probe was performed under high stringency conditions $\left(68^{\circ} \mathrm{C}\right)$ by the method of Sambrook et al..$^{25}$

The fragment sizes from at least three blots were averaged after measuring distances of band migration in comparison with molecular size markers. The reproducibility of ribotypes generated by $S m a I$ was examined by analysis of the same bacterial strain on three separate occasions.

\section{Pulsed-field gel electrophoresis}

Chromosomal DNA was prepared by a modification of the procedure of Chang and Taylor ${ }^{26}$ in which the cell suspensions were adjusted to $1.5 \times 10^{9}$ bacteria $/ \mathrm{ml}$. The agarose (Low-Melting-Point Agarose; Gibco-BRL) block containing genomic DNA was equilibrated at room temperature for $4 \mathrm{~h}$ in $100 \mu \mathrm{l}$ of SpeI buffer (BMC). Digestion with SpeI-which was chosen because it had been used previously to construct a physical and genetic map of the gonococcal chromosome of strains MS11-N198 and FA1090 27,28 -was performed at $37^{\circ} \mathrm{C}$ for $24 \mathrm{~h}$ in $100 \mu \mathrm{l}$ of fresh buffer with $5 \mathrm{U}$ of restriction endonuclease according to the manufacturer's instructions (BMC). After digestion, the agarose block was washed once in TE buffer (10 mM Tris, $1 \mathrm{~mm}$ EDTA, $\mathrm{pH} 8.0$ ) and loaded into the wells of an agarose (BioRad) $1 \% \mathrm{w} / \mathrm{v}$ gel, which was then sealed with the same concentration agarose in gel buffer. Electrophoresis was performed with the contour-clamped homo- 
geneous electric field (CHEF-DRII) system (BioRad), with agarose $1 \% \mathrm{w} / \mathrm{v}$ gels at $12^{\circ} \mathrm{C}$ in $0.5 \times$ Trisborate-EDTA (TBE) buffer $(100 \mathrm{~mm}$ Tris, $100 \mathrm{~mm}$ boric acid, 2 mм EDTA, $\mathrm{pH}$ 8.5). A constant voltage of $175 \mathrm{~V}$ was applied, with ramped pulse times of $0.2-54.2 \mathrm{~s}$ over a period of $24 \mathrm{~h}$. Under these conditions, fragments of $5-600 \mathrm{~kb}$ were separated and sized in comparison with lambda DNA concatemers (Promega) as molecular size markers. The presence of standard DNA mol. wt markers on each gel enabled comparisons to be made between gels. Fragment sizes and averages were determined from two-to-four replicates. Gels were stained with ethidium bromide, visualised with a UV- transilluminator, and photographed as described previously. ${ }^{10}$

\section{Results}

Antimicrobial susceptibility of $A H U^{-}$isolates of serovar $I A-2$

Five hundred and fifty-two arginine-requiring gonococcal isolates of serovar IA-2 which carried a cryptic plasmid were further subtyped on the basis of requiring either ornithine or citrulline as well as uracil and hypoxanthine $\left(\mathrm{OUH}^{-}: 459,83 \% ; \mathrm{CUH}^{-}: 61,11 \%\right)$ for growth; isolates which required only $\mathrm{O}$ and $\mathrm{H}$ (i.e., $\mathrm{OH}^{-}: 32,6 \%$ ) were also included since they belonged to serovar IA-2 and carried the 2.6-MDa plasmid. None carried $\beta$-lactamase-producing plasmids or transfer plasmids. The MIC range, MIC50 and MIC 90 values for these isolates of penicillin, tetracycline, erythromycin, spectinomycin, cefoxitin, and ceftriaxone (table I) indicated that the isolates rarely differed beyond a two-fold dilution difference, a difference not considered to be clinically significant. The most notable difference was seen with spectino- mycin MICs; $\mathrm{OUH}^{-}$and $\mathrm{CUH}^{-}$isolates were more susceptible (MIC ranges of 2.0 and $4.0-32.0 \mathrm{mg} / \mathrm{L}$, respectively) than $\mathrm{OH}^{-}$isolates (MIC range of $16 \cdot 0-32 \cdot 0 \mathrm{mg} / \mathrm{L}$ ).

\section{Ribotyping of gonococci}

Twenty-seven isolates were selected for further study to determine whether they could be differentiated by molecular methods. Ten of 27 gonococcal chromosomal DNA preparations were analysed in preliminary experiments with restriction endonucleases AvalI, $H$ HindII and SmaI to determine which enzymes would provide the greater discrimination for ribotyping. Hybridisation of AvalI fragments with the riboprobe yielded two ribotype patterns with four bands (either $17 \cdot 0,13 \cdot 2,6 \cdot 6$ and $3 \cdot 6 \mathrm{~kb}$, or $15 \cdot 2,6 \cdot 6,5 \cdot 1$ and $3 \cdot 6 \mathrm{~kb}$ ) for most strains (data not shown). Hybridisation of HindII fragments with the riboprobe produced a single ribotype pattern (data not shown). Analysis with SmaI produced highly resolved fragments suitable for analysis, and the $27 \mathrm{OUH}^{-}$or $\mathrm{CUH}^{-}$or $\mathrm{OH}^{-} / \mathrm{IA}$ $2 / 2 \cdot 6$ isolates were subtyped into five ribotypes designated I, II, III, IV and V. Fragment sizes ranged from 2.8 to $29.0 \mathrm{~kb}$, and five fragments $(23.1,12 \cdot 0,8.2,4.8$ and $2.8 \mathrm{~kb}$ ) were common across all types (fig. 1). These ribotypes did not correlate with a specific auxotype, and each ribotype differed from the other by the presence of only a single different sized fragment. The $12 \mathrm{OUH}^{-} / \mathrm{IA}-2$ isolates included all five ribotypes; the eight $\mathrm{CUH}^{-} / \mathrm{IA}-2$ isolates were subdivided into ribotype patterns I and V; and the seven $\mathrm{OH}^{-} / \mathrm{IA}-2$ isolates were subdivided into ribotype patterns I, II and V. Ribotype I dominated, representing 17 (65\%) of the 27 isolates.

The characteristic isolate banding patterns with SmaI remained unchanged when DNA was prepared

Table 1. Susceptibility of 552 serovar IA-2 isolates of three auxotypes to six antimicrobial agents

\begin{tabular}{|c|c|c|c|c|}
\hline \multirow{2}{*}{$\begin{array}{l}\text { Antimicrobial } \\
\text { agent }\end{array}$} & & \multicolumn{3}{|c|}{ MIC (mg/L) data for auxotype } \\
\hline & & $\begin{array}{c}\mathrm{OUH}^{-} \\
(\mathrm{n}=459)\end{array}$ & $\begin{array}{c}\mathrm{CUH}^{-} \\
(\mathrm{n}=61)\end{array}$ & $\begin{array}{c}\mathrm{OH}^{-} \\
(\mathrm{n}=32)\end{array}$ \\
\hline \multirow[t]{3}{*}{ Penicillin } & Range & $0.004-0.25$ & $0.004-0.032$ & $0.004-0.25$ \\
\hline & MIC50 & 0.016 & 0.016 & 0.016 \\
\hline & MIC90 & 0.016 & 0.016 & 0.032 \\
\hline \multirow[t]{3}{*}{ Tetracycline } & Range & $0.063-1.0$ & $0.063-0.5$ & $0.125-0.5$ \\
\hline & MIC50 & 0.25 & 0.25 & 0.25 \\
\hline & MIC90 & 0.5 & 0.5 & 0.5 \\
\hline \multirow[t]{3}{*}{ Erythromycin } & Range & $0.032-2 \cdot 0$ & $0.063-1.0$ & $0 \cdot 125-0.5$ \\
\hline & MIC50 & 0.5 & 0.5 & 0.5 \\
\hline & MIC90 & 1.0 & 1.0 & 1.0 \\
\hline \multirow[t]{3}{*}{ Spectinomycin } & Range & $4 \cdot 0-32 \cdot 0$ & $2 \cdot 0-32 \cdot 0$ & $16 \cdot 0-32 \cdot 0$ \\
\hline & MIC50 & $32 \cdot 0$ & $32 \cdot 0$ & $16 \cdot 0$ \\
\hline & MIC90 & $32 \cdot 0$ & $32 \cdot 0$ & $32 \cdot 0$ \\
\hline \multirow[t]{3}{*}{ Cefoxitin } & Range & $0.004-0.5$ & $0.125-0.25$ & $0.004-1.0$ \\
\hline & MIC50 & 0.25 & 0.25 & 0.25 \\
\hline & MIC90 & 0.25 & 0.25 & $0 \cdot 25$ \\
\hline \multirow[t]{3}{*}{ Ceftriaxone } & Range & $\leqslant 0.00025-0.002$ & $\leqslant 0.00025-0.002$ & $\leqslant 0.00025 \quad 0.002$ \\
\hline & MIC50 & 0.00025 & 0.00025 & 0.00025 \\
\hline & MIC90 & 0.0005 & 0.0005 & 0.0005 \\
\hline
\end{tabular}




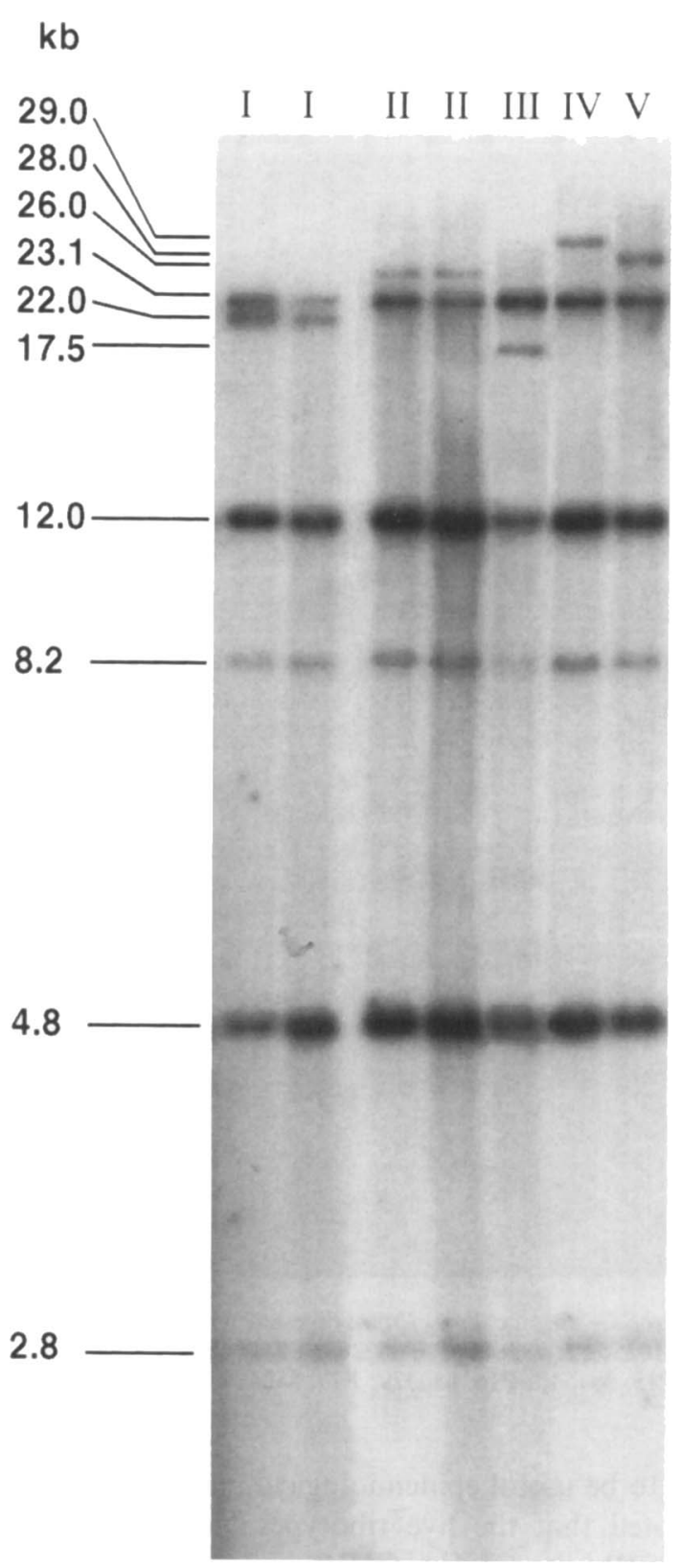

Fig. 1. Examples of ribotype patterns (designated I-V) obtained after hybridisation of the riboprobe with SmaI-digested chromosomal DNA. Strains shown are (left to right): nos. 882610, 880454 (ribotype I), 880420, 882208 (ribotype II), 882398 (ribotype III), 881035 (ribotype IV), 881540 (ribotype V).

from randomly selected strains grown on separate occasions, and the ribotype did not change after an individual strain was subcultured on at least six occasions.

\section{Restriction endonuclease analysis}

Gels of chromosomal DNA digested with SmaI and run under conditions for optimum ribotype discrimination were analysed retrospectively to evaluate RE analysis as a subtyping method (data not shown). Under the conditions described in the methods, SmaI digestion produced $80-100$ visible bands. The fragment size range $9 \cdot 7-27 \mathrm{~kb}$ was reproducible and stable, and was selected for band analysis, while DNA fragments of $<9.7 \mathrm{~kb}$ generally contained low in- tensity stained bands and fragments of $>27.0 \mathrm{~kb}$ were not well-resolved. Only one RE pattern, comprising 28 bands varying from $27 \cdot 0-9 \cdot 7 \mathrm{~kb}$ (data not shown), was observed for the 27 isolates.

\section{Analysis of 27 arginine-requiring gonococcal isolates by $P F G E$}

The 27 isolates were analysed further by PFGE. SpeI digestion of chromosomal DNA produced 10-15 fragments, ranging from $38-500 \mathrm{~kb}$, which were resolved into 17 patterns (fig. 2); the average molecular size of the bands in each pattern is shown in table II. The PFGE patterns observed for each isolate were reproducible (data not shown). All isolates had eight bands in common $(410 \cdot 0,107 \cdot 0,84 \cdot 0,78 \cdot 0,73 \cdot 0,63 \cdot 0$, 41.0 and $38.0 \mathrm{~kb}$ ). Twenty-five of the 27 isolates also had a $176 \cdot 0-\mathrm{kb}$ fragment; the exceptions were isolates 880397 and 880420 . The $12 \mathrm{OUH}^{-} / \mathrm{IA}-2$ isolates produced 10 distinct PFGE patterns, the eight $\mathrm{CUH}^{-} / \mathrm{IA}-2$ isolates produced five PFGE patterns, and the seven $\mathrm{OH}^{-} / \mathrm{IA}-2$ isolates produced five PFGE patterns (table III). P15 was found in both the $\mathrm{CUH}^{-} / \mathrm{IA}-2$ group and the $\mathrm{OUH}^{-} / \mathrm{IA}-2$ group, P1 was found in the $\mathrm{OUH}^{-} / \mathrm{IA}-2$ and $\mathrm{OH}^{-} / \mathrm{IA}-2$ group, and $\mathrm{P} 3$ was found in the $\mathrm{CUH}^{-} / \mathrm{IA}-2$ and $\mathrm{OH}^{-} / \mathrm{IA}-2$ group. The 17 isolates belonging to ribotype I were subtyped further into 10 PFGE patterns; four isolates belonging to ribotype II were subtyped into four PFGE patterns; two isolates belonging to ribotype III were subtyped into two PFGE patterns; and three isolates belonging to ribotype $\mathrm{V}$ were subtyped into three PFGE patterns.

In conclusion, the 27 IA-2 isolates were represented by three arginine-requiring auxotypes, one RE pattern, five ribotype patterns and 17 SpeI PFGE patterns (table III).

\section{Discussion}

Several typing systems have been developed to characterise individual strains of $N$. gonorrhoeae, including auxotype, serotype, plasmid content and antimicrobial susceptibility determination. In previous studies, the combination of antimicrobial susceptibility testing with plasmid content analysis, serotyping and auxotyping has been shown to provide greater discrimination between isolates than the use of only one of these techniques. ${ }^{729}$ However, these methods have not been successful in distinguishing $\mathrm{OUH}^{-}$, $\mathrm{CUH}^{-}$or $\mathrm{OH}^{-}$isolates (i.e., $\mathrm{AHU}^{-}$) of serovar IA-2.

Although several molecular fingerprinting techniques, such as RE analysis, ribotyping and PFGE analysis, have been used for typing $N$. gonorrhoeae, ${ }^{8,10,11,13}$ none of the auxotype/serotype classes described in this study has been analysed previously with these methods. Previous studies on RE pattern analysis of $N$. gonorrhoeae $e^{8,30,31}$ used polyacrylamide $4 \% \mathrm{w} / \mathrm{v}$ gels to study fragments of 


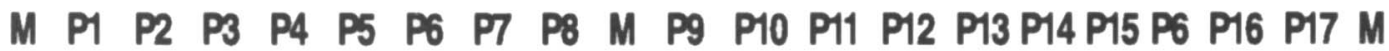

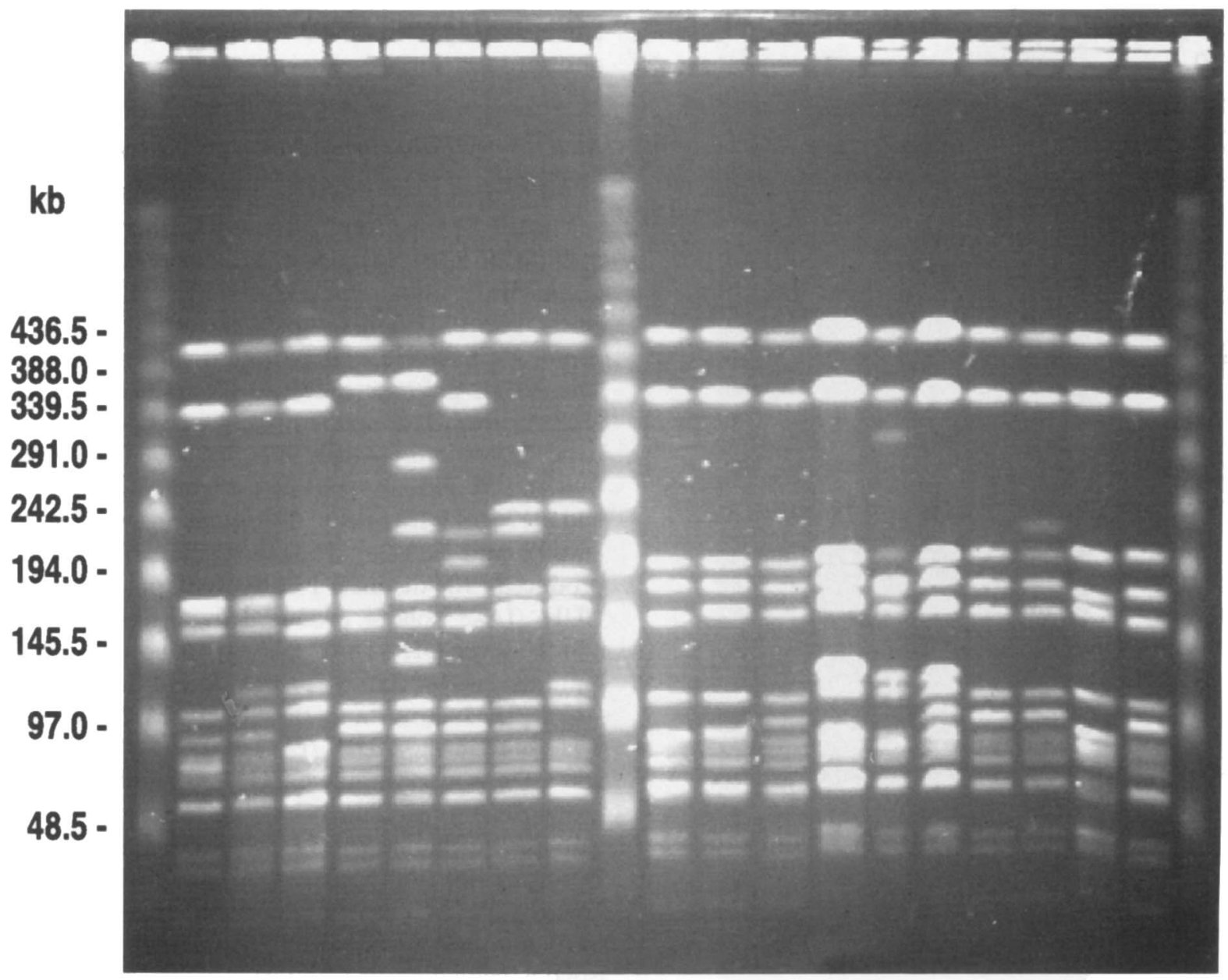

Fig. 2. Examples of PFGE patterns obtained following digestion of $N$. gonorrhoeae chromosomal DNA digested with SpeI. M, lambda concatemers; P (pattern) 1, strain no. 881506; P2, 883171; P3, 880270; P4, 881035; P5, 882642; P6, 882208; P7, 882521; P8, 882398; P9, 882610; P10, 882132; P11, 882306; P12, 881342; P13, 880375; P14, 883212; P15, 881540; P16, 880379; P17, 880420.

HindIII-digested DNA of $<2 \mathrm{~kb}$. However, other studies found that this enzyme was not useful for discriminating $N$. gonorrhoeae isolates by ribotyping when an agarose gel system was used. ${ }^{10}$ For this reason, an agarose gel system which resolved fragments of SmaI-digested DNA in the $9 \cdot 0-27 \cdot 0$-kb range was used. Previous studies have also indicated that RE analysis can distinguish isolates belonging to the same serovar, ${ }^{8.30 .31}$ but this was not achieved by the conditions and enzyme used for RE analysis in the present study. The limitations of RE analysis, including the number of bands produced and difficulties in interpretation, have been noted previously, ${ }^{32}$ and for these reasons, it is not used routinely as a subtyping method.

In general, RE analysis has been more successful when combined with hybridisation to a gene probe, such as a ribosomal nucleic acid gene, to select a small number of fragments. ${ }^{33}$ In the present study, the number of bands to interpret by ribotyping was reduced to between six and seven, compared to $\geqslant 80$ for RE typing. The 27 isolates were classified into five ribotype patterns, and no isolate was non-typable. This suggested that there may be sufficient heterogeneity of rRNA patterns within $N$. gonorrhoeae for them to be useful epidemiological markers. It should be noted that the five ribotypes did not recognise exclusively the $\mathrm{OUH}^{-}, \mathrm{CUH}^{-}$or $\mathrm{OH}^{-} / \mathrm{IA}-2 / 2 \cdot 6$ isolates in the present study; other isolates of different auxotype/serotype classes also had these ribotypes. ${ }^{34}$ Previous studies ${ }^{10.11}$ have also shown that common DNA bands are present in the ribotype patterns of all $N$. gonorrhoeae isolates, indicating the conserved nature of the rRNA genes within the species. There was no absolute correlation between rRNA gene restriction patterns and auxotype/serotype class, as has also been observed previously. ${ }^{10,11}$

Recently, DNA macrorestriction analysis by PFGE has been used to compare chromosomal restriction patterns in a number of genera. ${ }^{35-38} \mathrm{~A}$ previous study of PFGE patterns generated by SpeI or NheI digests of $N$. gonorrhoeae differentiated 48 isolates of different auxotype/serotype classes into 38 SpeI PFGE groups or 40 NheI groups. ${ }^{14}$ Since the classes of the isolates in the present study differed from those examined previously, and since fragment size was not indicated, we were unable to compare the data with those obtained previously. ${ }^{14}$ However, both studies demonstrated that PFGE could subtype isolates within the same 
Table II. PFGE patterns of 27 arginine-requiring gonococcal isolates of serovar IA-2

\begin{tabular}{|c|c|c|c|c|c|c|c|c|c|c|c|c|c|c|c|c|c|}
\hline \multirow{2}{*}{$\begin{array}{l}\text { Fragment } \\
\text { size }(k b)\end{array}$} & \multicolumn{17}{|c|}{ PFGE pattern number } \\
\hline & P1 & P2 & P3 & P4 & P5 & P6 & P7 & P8 & P9 & P10 & P11 & P12 & P13 & P14 & P15 & P16 & P17 \\
\hline $410 \cdot 0$ & + & + & + & + & + & + & + & + & + & + & + & + & + & + & + & + & + \\
\hline 367.0 & - & - & - & + & + & - & - & - & - & - & - & - & - & - & - & - & - \\
\hline $339 \cdot 5$ & + & + & + & - & - & + & - & - & + & + & + & + & + & + & + & + & + \\
\hline 297.0 & - & - & - & - & - & - & - & - & - & - & - & - & + & - & - & - & - \\
\hline 275.0 & - & - & - & - & + & - & - & - & - & - & - & - & - & - & - & - & - \\
\hline $242 \cdot 5$ & - & - & - & - & - & - & + & + & - & - & - & - & - & - & - & - & - \\
\hline 228.0 & - & - & - & - & + & + & + & - & - & - & - & - & - & - & - & - & - \\
\hline 207.0 & - & - & - & - & - & - & - & - & - & - & - & - & - & - & - & - & + \\
\hline $200 \cdot 0$ & - & - & - & - & - & + & - & - & - & - & - & - & - & - & + & + & - \\
\hline 193.0 & - & - & - & - & - & - & - & - & + & + & + & + & + & + & - & - & - \\
\hline 183.0 & - & - & - & - & - & - & - & + & - & - & - & - & - & - & - & - & - \\
\hline 176.0 & + & + & + & + & + & + & + & + & + & + & + & + & + & + & + & - & - \\
\hline 168.0 & - & - & - & - & - & - & - & - & - & - & - & - & - & - & - & + & + \\
\hline 167.0 & - & - & - & - & - & - & + & + & - & - & - & - & - & - & - & - & - \\
\hline $159 \cdot 0$ & + & + & + & + & + & + & - & - & - & + & + & + & + & + & + & + & + \\
\hline $149 \cdot 0$ & - & - & - & - & - & - & - & - & + & - & - & - & - & - & - & - & - \\
\hline 137.0 & - & - & - & - & + & - & - & - & - & - & - & - & - & - & - & - & - \\
\hline 117.0 & - & + & + & - & - & - & - & + & - & - & - & + & + & + & - & - & - \\
\hline $107 \cdot 0$ & + & + & + & + & + & + & + & + & + & + & + & + & + & + & + & + & + \\
\hline $95 \cdot 0$ & + & + & - & + & + & + & + & - & - & - & + & - & - & + & + & - & + \\
\hline 84.0 & + & + & + & + & + & + & + & + & + & + & + & + & + & + & + & + & + \\
\hline $78 \cdot 0$ & + & + & + & + & + & + & + & + & + & + & + & + & + & + & + & + & + \\
\hline $73 \cdot 0$ & + & + & + & + & + & + & + & + & + & + & + & + & + & + & + & + & + \\
\hline $63 \cdot 0$ & + & + & + & + & + & + & + & + & + & + & + & + & + & + & + & + & + \\
\hline $59 \cdot 0$ & - & - & - & - & - & - & - & - & - & - & - & - & - & - & - & + & - \\
\hline $41 \cdot 0$ & + & + & + & + & + & + & + & + & + & + & + & + & + & + & + & + & + \\
\hline 38.0 & + & + & + & + & + & + & + & + & + & + & + & + & + & + & + & + & + \\
\hline
\end{tabular}

Strain nos. generating each individual pattern were as follows: P1, 881506, 883342; P2, 883171; P3, 880270, 880454, 881097, 883099; P4, 881035; P5, 882642; P6, 882208; P7, 882521; P8, 882398; P9, 882610, 883729; P10, 882132; P11, 882306, 883463; P12, 881342, 882376, 882794; P13, 880375; P14, 883212; P15, 881540, 882245, 883122; P16, 880379; and P17, 880420.

Table III. Relationship between auxotype/serotype, ribotype and PFGE pattern for 27 gonococcal isolates

\begin{tabular}{|c|c|c|c|}
\hline Strain no. & $\begin{array}{l}\text { Auxotype/ } \\
\text { serotype }\end{array}$ & $\begin{array}{c}\text { Ribotype } \\
\text { pattern }\end{array}$ & $\begin{array}{l}\text { PFGE } \\
\text { pattern }\end{array}$ \\
\hline 880375 & & & P13 \\
\hline 882306 & & & P11 \\
\hline 883122 & $\mathrm{OUH}^{-} / \mathrm{IA}-2$ & I & P15 \\
\hline 883171 & & & P2 \\
\hline $883342 J$ & & & P1 \\
\hline 883463 & $\mathrm{OUH}^{-} / \mathrm{IA}-2$ & V & P11 \\
\hline 880420 ) & & & P17 \\
\hline 882208 & $\mathrm{OUH}^{-} / \mathrm{IA}-2$ & II & P6 \\
\hline 882245 J & & & P15 \\
\hline 881035 & $\mathrm{OUH}^{-} / \mathrm{IA}-2$ & IV & P4 \\
\hline 882398 & $\mathrm{OUH}^{-} / \mathrm{IA}-2$ & III & P8 \\
\hline 882521 & $\mathrm{OUH}^{-} / \mathrm{IA}-2$ & III & P7 \\
\hline 880270 ) & & & P3 \\
\hline 880379 & & & P16 \\
\hline 880454 & & & P3 \\
\hline 882132 & $\mathrm{CUH}^{-} / \mathrm{IA}-2$ & I & P10 \\
\hline 882610 & & & P9 \\
\hline 883099 & & & P3 \\
\hline 883729$)$ & & & P9 \\
\hline 881540 & $\mathrm{CUH}^{-} / \mathrm{IA}-2$ & V & P15 \\
\hline 881097$)$ & & & P3 \\
\hline 881342 & & & P12 \\
\hline 881506 & $\mathrm{OH}^{-} / \mathrm{IA}-2$ & I & P1 \\
\hline 882376 & & & P12 \\
\hline 882794 J & & & P12 \\
\hline 882642 & $\mathrm{OH}^{-} / \mathrm{IA}-2$ & V & P5 \\
\hline 883212 & $\mathrm{OH}^{-} / \mathrm{IA}-2$ & II & P14 \\
\hline
\end{tabular}

auxotype/serotype classes. In this study, PFGE typing provided greater differentiation than auxotype/ serotype typing, RE typing or ribotyping alone. Phenotypically similar but epidemiologically unrelated strains could also be differentiated, and this should be a powerful method for confirming the identity of epidemiologically related isolates. ${ }^{39}$

The present results show that isolates which appear to be clonal by classical typing methods can be distinguished by ribotyping and PFGE. All of the ribotype groups, and most of the different PFGE types, showed only one or two band differences from a conserved core profile present in all isolates, differences which could be explained by a single genetic event, such as deletion, insertion, inversion or mutation. These results reflect the high recombination rates of $N$. gonorrhoeae and provide further evidence for its non-clonal population structure. ${ }^{12}$

One of the limitations of both ribotyping and PFGE typing in $N$. gonorrhoeae is the lack of standardised methods and banding pattern numeration for recording ribotypes and PFGE patterns between laboratories, thereby making it almost impossible to compare data. In addition, PFGE may provide too much discrimination for use in population studies. The strength of PFGE as a typing scheme may ultimately be in its ability to confirm identity-i.e., in nosocomial infections or well-characterised epidemiological outbreaks - rather than to provide broad discrimi- 
nation in biologically similar, but epidemiologically distinct isolates.

We thank M. Pauzé (National Laboratory for Sexually Transmitted Diseases. Laboratory Centre for Disease Control. Ottawa) for performing auxotype, serovar, MIC and plasmid content

\section{References}

1. Catlin BW Nutritional profiles of Neisseria gonorrhoeae, Neisseria meningitidis and Neisseria lactamica in chemically defined media and the use of growth requirements for gonococcal typing. $J$ Infect Dis $1973 ; 128$ : 178-194.

2. Picard FJ, Dillon JR. Biochemical and genetic studies with arginine and proline auxotrophs of Neisseria gonorrhoeae. Can J Microbiol 1989; 35: 1069-1075.

3. Catlin BW. Nash EH. Arginine biosynthesis in gonococci isolated from patients. In: Brooks GF, Gotschlich EC, Holmes K K, Sawyer WD, Young FE (eds) Immunobiology of Neisseria gonorrhoeae. Washington. DC. American Society for Microbiology, 1978:1-8.

4. Eisenstein BI, Lee TJ, Sparling PF. Penicillin sensitivity and serum resistance are independent attributes of strains of Neisseria gonorrhoeae causing disseminated gonococcal infections. Infect Immun 1977; 15: 834-841.

5. Schoolnik GK, Buchanan TM. Holmes KK. Gonococci causing disseminated gonococcal infection are resistant to the bactericidal action of normal human sera. $J$ Clin Invest 1976; 58: 1163-1173.

6. Dillon JR, Bygdeman SM, Sandström EG. Serological ecology of Neisseria gonorrhoeae (PPNG and non-PPNG) strains : Canadian perspective. Genitourin Med 1987; 63: 160-168.

7. Dillon JR, Rahman M, Yeung K-H. Discriminatory power of typing schemes based on Simpson's index of diversity for Neisseria gonorrhoeae. J Clin Microbiol 1993; 31 2831-2833.

8. Falk ES, Bjorvatn B. Danielsson D, Kristiansen BE, Melby K, Sorensen $B$. Restriction endonuclease fingerprinting of chromosomal DNA of Neisseria gonorrhoeae. Acta Pathol Microbiol Immunol Scand Sect B 1984; 92 : 271-278.

9. Poh CL. Ocampo JC, Sng EH. Bygdeman SM. Rapid in-situ generation of DNA restriction endonuclease patterns for Neisseria gonorrhoeae. J Clin Microbiol 1989; 27: $2784-2788$.

10. Ng L-K, Dillon JR. Typing by serovar, antibiogram, plasmid content. riboprobing, and isoenzyme typing to determine whether Neisseria gonorrhoeae isolates requiring proline, citrulline, and uracil for growth are clonal. J Clin Microbiol $1993 ; 31: 1555-1561$.

11. Poh CL, Khng HP, Lim CK, Loh GK. Molecular typing of Neisseria gonorrhoeae by restriction fragment length polymorphisms. Genitourin Med 1992; 68: 106-110.

12. O'Rourke M. Spratt BG. Further evidence for the non-clonal population structure of Neisseria gonorrhoeae: extensive genetic diversity within isolates of the same electrophoretic type. Microbiol 1994; 140: 1285-1290.

13. Dillon JR. Li H. Comparison of pulsed field gel electrophoresis to ribotyping for discriminating between isolates of Neisseria gonorrhoeae of auxotype/serovar classes NR/IA5 and A/IA-2, abstr. 229. Abstracts of the 10th International Meeting of the International Society for STD Research, Helsinki, Finland, 1993: 229.

14. Poh CL, Lau QC. Subtyping of Neisseria gonorrhoeae auxotypeserovar groups by pulsed-field gel electrophoresis. $J$.Med Microbiol 1993; 38: 366-370.

15. Dillon JR. Laboratory methods for Neisseria gonorrhoeae. Publication H47-58/1983E, Ottawa, Ontario, Canada. Health and Welfare Canada, 1983.

16. Dillon JR, Carballo M, King SD, Brathwaite AR. Auxotypes, plasmid contents, and serovars of gonococcal strains (PPNG and non-PPNG) from Jamaica. Genitourin Med $1987 ; 63: 233-238$

17. Brosius J, Ullrich A, Raker MA et al. Construction and fine mapping of recombinant plasmids containing the $r r n B$ analysis. We also thank Dr K.-H. Yeung (National Laboratory for Sexually Transmitted Diseases, Laboratory Centre for Disease Control, Ottawa) for statistical analysis of the data and Dr L.-K. Ng (Department of Microbiology and Immunology, University of Ottawa) for her helpful comments during the study and her critical reading of the manuscript. These data were presented in part at the 10th International Meeting of the International Society for STD Research (Helsinki, Finland, 1993) ribosomal RNA operon of E. coli. Plasmid 1981; 6: $112-118$.

18. Hendry AT, Stewart IO. Auxanographic grouping and typing of Neisseria gonorrhoeae. Can J Microbiol 1979; 25: $512-521$

19. Knapp JS, Tam MR, Nowinski RC, Holmes KK, Sandström EG. Serological classification of Neisseria gonorrhoeae with use of monoclonal antibodies to gonococcal outer membrane protein I. J Infect Dis 1984; 150: 4448.

20. Dillon JR, Pauzé M. Relationship between plasmid content and auxotype in Neisseria gonorrhoeae isolates. Infect Immun 1981: 33: $625-628$

21. National Committee for Clinical Laboratory Standards. Approved standard M7-A2. Standard methods for dilution antimicrobial tests with bacteria that grow aerobically, 2 nd edn. Villanova, PA, National Committee for Clinical Laboratory Standards. 1990.

22. Dillon JR, Nasim A, Nestmann ER (eds). Recombinant DNA methodology. New York, John Wiley and Sons. 1985.

23. Feinberg AP, Vogelstein B. Addendum: "A technique for radiolabeling DNA restriction endonuclease fragments to high specific activity." Anal Biochem 1984; 137: 266-267.

24. Chomczynski P, Qasba PK. Alkaline transfer of DNA to plastic membrane. Biochem Biophys Res Comm 1984; 122: 340-344.

25. Sambrook J, Fritsch EF, Maniatis T (eds). Molecular cloning: a laboratory manual, 2nd edn. Cold Spring Harbor, New York, Cold Spring Harbor Laboratory Press. 1989.

26. Chang N, Taylor DE. Use of pulsed-field agarose gel electrophoresis to size genomes of Campylobacter species and to construct a SalI map of Campylobacter jejuni UA 580. J Bacteriol 1990; 172: 5211-5217.

27. Bihimaier A, Romling U, Meyer TF, Tummler B, Gibbs CP Physical and genetic map of the Neisseria gonorrhoeae strain MS11-N198 chromosome. Mol Microbiol 1991; 5: 2529-2539.

28. Dempsey JAF, Litaker W. Madhure A, Snodgrass TL, Cannon JG. Physical map of the chromosome of Neisseria gonorrhoeae FA1090 with locations of genetic markers, including opa and pil genes. $J$ Bacteriol 1991 ; 173: 5476-5486.

29. Danielsson D, Bygdeman S, Kallings I. Epidemiology of gonorrhoea: serogroup, antibiotic susceptibility and auxotype patterns of consecutive gonococcal isolates from ten different areas of Sweden. Scand J Infect Dis 1983; 15 $33-42$

30. Falk ES, Danielsson D, Bjorvatn B, Melby K, Sorensen B, Kristiansen BE. Genomic fingerprinting in the epidemiology of gonorrhoeae. Acta Dermatol Venereol 1985; 65: 235-239

31. Falk ES, Danielsson D, Bjorvatn B et al. Phenotypic and genotypic characterization of penicillinase-producing strains of Neisseria gonorrhoeae. Acta Pathol Microbiol Immunol Scand Sect B 1985; 93: 91-97.

32. Owen RJ. Chromosomal DNA fingerprinting - a new method of species and strain identification applicable to microbial pathogens. J Med Microbiol 1989; 30: 89-99.

33. Bingen EH, Denamur E, Elion J. Use of ribotyping in epidemiological surveillance of nosocomial outbreaks. Clin Microbiol Rev 1994; 7: 311-327.

34. Li H. MSc Thesis, 1993. Evaluation of molecular typing methods to discriminate between isolates of Neisseria gonorrhoeae, restriction endonuclease analysis, ribotyping and pulsed field gel electrophoresis. University of Ottawa, Ottawa, Ontario, Canada.

35. Allerdet-Servent A, Bouziges N, Carles-Nurit MJ, Boung G, Gouby A, Ramuz M. Use of low-frequency-cleavage restriction endonucleases for DNA analysis in epidemiological investigations of nosocomial bacterial infections. $J$ Clin Microbiol 1989; 27: 2057-2061. 
36. Anderson DJ, Kuhns JS, Vasil ML, Gerding DN, Janoff EN. DNA fingerprinting by pulsed field gel electrophoresis and ribotyping to distinguish Pseudomonas cepacia isolates from a nosocomial outbreak. J Clin Microbiol 1991; 29: 648-649.

37. Murray BE, Singh KV, Heath JD, Sharma BR, Weinstock GM. Comparison of genomic DNAs of different enterococcal isolates using restriction endonucleases with infrequent recognition sites. J Clin Microbiol 1990; 28: 2059-2063.
38. Ott M, Bender L, Marre R, Hacker J. Pulsed field electrophoresis of genomic restriction fragments for the detection of nosocomial Legionella pneumophila in hospital water supplies. J Clin Microbiol 1991; 29: 813-815.

39. Xia M, Whittington WL, Knapp JS, Holmes KK, Roberts MC. Epidemiologic analysis of Neisseria gonorrhoeae by pulsed-field gel electrophoresis. Proceedings of the Ninth International Pathogenic Neisseria Conference, 1994. Abstract p. 411. 